\title{
ALIANZA Y COMUNIÓN: LA POESÍA COMO SACRAMENTO EN LA OBRA DE ANDRÉS SÁNCHEZ ROBAYNA
}

\author{
Carlos PEINADO ELLIOT \\ Universidad de Sevilla \\ cpeinado@us.es
}

\begin{abstract}
Sacrificio (sacrum facere). Todo poema es una operación sacrificial. Aspira a hacer sagrado aquello que ha podido tocar con la palabra (Sánchez Robayna, 2016: 485).
\end{abstract}

$\mathrm{E}$ n la última entrega de sus Diarios, Andrés Sánchez Robayna (2016: 134) se pregunta «si es verdad que ha muerto el concepto trascendental y metafísico que el romanticismo alemán atribuyó al arte». La cursiva (que vuelve a repetirse en su reflexión) pretende mostrar las contradicciones del pensamiento postmoderno ( $¿$ LLa postmodernidad no cuestiona la idea misma de verdad?» (2016:134)) en defensa de una poesía como conocimiento, eje vertebrador de la aventura poética de Sánchez Robayna, que se enraíza precisamente en la tradición que tiene como punto de arranque o de ruptura el Romanticismo.

Una lectura de la segunda parte del ensayo Deseo, imagen, lugar de la palabra, publicada posteriormente como «Epílogo» al volumen En el cuerpo del mundo, nos revela las líneas principales de la poética del autor, aclarándonos la vinculación entre la tradición romántica y la concepción sacramental de la poesía. Se trata de un texto de gran interés pues, partiendo de las célebres palabras de Mallarmé sobre la situación del poeta en la sociedad contemporánea ${ }^{1}$ (palabras que «conquistaron en otro tiempo [su] casi completa adhesión»), plantea algunas diferencias que permitirían profundizar en la evolución de la poesía de Sánchez Robayna ${ }^{2}$. En consonancia con Mallarmé, observa la progresiva asfixia a la que la cultura actual somete a toda obra del espíritu a través de la degradación de la palabra, al tiempo que identifica este proceso con el predominio del nihilismo ${ }^{3}$ y la desacralización del mundo (1995: 358): «Son incontables las anuencias que esta situación ha

\footnotetext{
1 «Para mí, el caso de un poeta, en esta sociedad que no le permite vivir, es el caso de un hombre que se aísla para esculpir su propia tumba» (Sánchez Robayna, 1995: 354).

${ }^{2}$ No es este, sin embargo, el momento de profundizar en esta evolución.

${ }^{3}$ Cfr. Sánchez Robayna (1995: 358): «Se diría que no han hecho más que agudizarse y agravarse las condiciones y las consecuencias del "nihilismo" posterior a la "muerte de Dios"»
} 


\section{Tropelías. Revista de Teoría de la Literatura y Literatura Comparada, 29 (2018)}

Alianza y comunión: la poesía como sacramento en la obra de Andrés Sánchez Robayna

alcanzado entre quienes dan por irremediablemente perdida la antigua "cultura" de lo sagrado y su validez para el mundo de hoy». Se comienza a intuir en este punto que la finalidad del poeta consistirá en la re-sacralización del mundo, a través de una palabra poética a la que se haya devuelto «un poder de conjuro, una energía perdida por el uso» (1995: 358).

Andrés Sánchez Robayna encuentra el origen de este proceso nihilista en la Ilustración (1995: 358-359), opuesta a toda idea de trascendencia y fundamento de los realismos actuales

[...] cuya concepción de lo poético [...] niega toda dimensión espiritual, [...] y cuyos valores -los valores utilitaristas- deben apoyarse una y otra vez, a la larga, en los principios ilustrados, opuestos a la idea de "trascendencia", y lo que ellos significan: una condena radical de lo "imaginario" y una completa negación de lo sagrado.

Frente a «las promesas incumplidas de la razón ilustrada» (1995: 359), que ha pretendido eliminar la trascendencia de lo humano, Sánchez Robayna alude a una concepción de la palabra poética que se remonta al orfismo y al pitagorismo, pero que encuentra su formalización moderna en el romanticismo, crisol de corrientes herméticas que combinan bien con la filosofía idealista y a cuya tradición pertenece el poeta canario ${ }^{4}$. Precisamente en este contexto nihilista ha de situarse la concepción sacramental de la poesía (1995: 360):

Con todo, no puede decirse que la situación del poeta en nuestro tiempo sea idéntica a la experimentada por Mallarmé. Se diría que de la actitud "órfica" de éste ha heredado el siglo XX un sentido sacramental de la práctica de la poesía - uno de los valores, por cierto, más estimados por algunos poetas contemporáneos-, esto es, antes que cualquier cosa, un "signo sensible" de interioridad espiritual, una suerte de mysterium milagrosamente traducido en la palabra. Se trata de una espiritualidad que, además de ver en el lenguaje el hecho poético por excelencia, y de confundirse con él (como dijo del autor de Hérodiade uno de sus discípulos), difícilmente concibe ninguna práctica poética fuera de un designio de religación. Lo que ha cambiado, desde Mallarmé a nosotros, es que esa extrema conciencia del lenguaje, en el que reside, sí, el hecho poético por excelencia, lo es también de que hay algo más allá de él, y que el misterio del lenguaje nos remite a la pregunta por lo que está más allá del lenguaje.

Se entrelazan en la cita anterior algunos de los conceptos que habrá que abordar en el presente trabajo: sacramentalidad, misterio, espiritualidad, religación. Partiendo de las amputaciones que la razón ilustrada ha causado (la separación entre naturaleza y hombre, entre unos hombres y otros, entre la parte racional del hombre y el resto de dimensiones que lo humano encierra), la palabra poética se convierte en símbolo que reunifica, que lleva a la unidad lo dividido y roto por el nihilismo. Sánchez Robayna afirma así una transformación del proyecto de Mallarmé al buscar un «más allá del lenguaje» (Sánchez Robayna, 1995: 360) que se encarna en poemas como «Más allá de los árboles», y que re-ligue con el misterio: «Un misterio o una sacramentalidad del sentido y el

\footnotetext{
${ }^{4}$ Cfr. las siguientes declaraciones en una entrevista (de Eusebio, 2015: 55-56): «Tal vez la única manera de entender racionalmente esa conciliación [con el misterio] es viendo el conocimiento poético como un saber en sí, pero un saber del misterio, es decir, una misteriosofía. Por eso la poesía enlaza con las tradiciones ocultistas, de las que en muchos sentidos no se distingue, y es del todo congruente con su búsqueda y con sus hallazgos el interés que muchos poetas han experimentado por el saber oculto, las doctrinas herméticas, la magia y el esoterismo, porque de una manera u otra en todo poema late la visión del mundo como gran obra mágica. Novalis, por ejemplo, asocia las figuras del poeta y el mago.»
} 
lugar del hombre en el mundo que necesariamente desemboca en un encuentro o reencuentro con la presencia» (1995: 361).

La cita anterior pone en relación la poética de Andrés Sánchez Robayna con el libro de George Steiner Presencias reales. Precisamente Steiner sitúa a finales del XIX la crisis que cuestiona la confianza en el lenguaje, y en ella emplaza la poética de Mallarmé, quien parte no de la presencia sino de la «ausencia real» ${ }^{5}$. En la ruptura del contrato referencial ve Steiner la recuperación de las «energías mágicas» de la palabra, de su «potencial perdido para la bendición o el anatema, para el conjuro y el descubrimiento» (2001: 115). Steiner concluye afirmando en su ensayo la necesidad de la presencia de Dios (o del peso sentido de su ausencia) como condición para alcanzar «ciertas dimensiones del pensamiento y la creatividad» (2001: 256).

En La inminencia, Sánchez Robayna (1996: 226) manifiesta su acuerdo con la argumentación principal del libro de Steiner:

En cuanto a mi parecer, imposible no tener con estas casi siempre admirables páginas -más allá de matices y aspectos diversos que no sé si he comprendido de manera correcta- una casi completa identificación. He mantenido durante estos últimos años más de una amistosa discusión sobre esta misma idea central. Y hace muy poco me he visto argumentando, ante un grupo de conocidos, posiciones coincidentes con las que aquí se defienden (Me acompañaba en esos puntos de vista, por cierto, J. P., que compartía la idea y el sentido de la recuperación de una indesplazable sacralidad en el espíritu de la creación actual, tan banalizada, tan trivializada [...]).

Opone Sánchez Robayna (1996: 228), al igual que Steiner, una interpretación religiosa de la obra de arte (recordando nuevamente el concepto zubiriano de religación -a su entender, fundamental-) a las «muertes del sentido» (Sánchez Robayna, 1996: 228) -muerte de Dios- de la modernidad. Más aún, hace suya la cuestión sobre si es posible un modelo positivista y profano de la experiencia estética. Esta pregunta lleva en su caso a defender una concepción sacramental de la poesía (Sánchez Robayna, 1996: 229):

Hace tiempo que, por mi parte, no sólo me he hecho la pregunta que formula Steiner, sino que tengo la impresión, también, de que nunca he estado haciendo otra cosa que intentar responderla. La substanciación metafísica está en lo que escribo desde un principio. Y una formulación específicamente religiosa desde hace algunos años. «La poética - escribe Steiner- busca dilucidar la incomunicación de nuestros encuentros con la muerte.» El movimiento en la noche. Sacramentalidad y liturgia.

Si contrastamos Presencias reales con el ensayo de Sánchez Robayna «Mallarmé y el saber de la nada», encontramos cómo emplea unos términos similares a los de Steiner: la crisis en la que se sumerge Mallarmé procede de su contacto con la Nada, fruto de su reflexión poética, que le ha conducido a la ruptura del contrato o pacto entre la palabra y el mundo,

[...] cuya abrogación reside para el autor de Herodías, ante todo -una vez "aniquilado" Dios, una vez destruida toda "presencia"-, en la materialidad del verbo, y cuya consecuencia es la disolución o desaparición de la referencialidad, esto es, la palabra que, al cabo, se significa sólo a sí misma (Sánchez Robayna, 1998: 13-14).

\footnotetext{
${ }^{5}$ Sobre el «nihilismo ontológico» de Mallarmé, cfr. Steiner (2001:113).
} 


\section{Tropelías. Revista de Teoría de la Literatura y Literatura Comparada, 29 (2018)} Alianza y comunión: la poesía como sacramento en la obra de Andrés Sánchez Robayna

Así pues, se marca un punto de inflexión, o una diferencia, entre una poética construida sobre la ausencia y la muerte de Dios, frente a otra que parece erigirse sobre la presencia. Tal vez podríamos observar una diferencia entre «la dramática "Nada" a la que Mallarmé alude» y la vacuidad o «Shúnyata» budista (Sánchez Robayna, 1998: 16).

No obstante, al comentar Pour un tombeau d'Anatole, el poeta observa cómo la palabra poética persigue resucitar al hijo muerto, «hacerlo revivir en él» (Sánchez Robayna, 1998: 19), señalando el fin de la palabra más que nunca órfica en su descenso al lugar de la muerte para convertirse en una «palabra de resurrección» (1998: 20). De igual modo, Deseo, imagen, lugar de la palabra concluye con una defensa de la poesía como liberación del poder espiritual de la palabra, capaz de reunificar al hombre con el mundo. Esto solo es posible «reencontrando lo sagrado, las fuerzas de una espiritualidad capaz de destruir los límites que separan al hombre de sí mismo y lo han alejado de su conciencia de la temporalidad y de la muerte» (Sánchez Robayna, 1995: 362). Una indagación en la temporalidad y la muerte que bucea en el misterio para religar lo separado. De este modo, retoma la recuperación del sentido mágico de la palabra en Mallarmé, para la cual es necesaria una purificación continua (debido a la corrupción que la sociedad actual provoca en un lenguaje concebido exclusivamente como un instrumento superficial), pero propugna un «más allá del lenguaje», una presencia a la que toda palabra poética apunta. Así se observa en el final del artículo que, nuevamente, vuelve a emplear el concepto de George Steiner (Sánchez Robayna, 1995: 363): «¿Puede ser otra, acaso, su función más alta y verdadera: la restitución de la presencia bajo el signo de la religación del mundo visible y del mundo invisible?». Por ello, el poeta canario puede reconocerse como poeta de lo real ${ }^{6}$.

\section{Acercamiento al concepto de lo sagrado en la obra de Sánchez Robayna}

Aunque no hay espacio para profundizar exhaustivamente en la aparición y desarrollo de este concepto en la obra del autor, es necesario aclarar someramente (en la medida de lo posible) su contenido. No identifica lo sagrado con la religión, pues considera que lo sagrado es el fondo previo del que proceden las diversas religiones, las precede y sobrevivirá a ellas. El concepto de lo sagrado se une inextricablemente, como observó Rudolf Otto en Lo santo, al sentimiento de misterio ${ }^{7}$. Así lo repite en varias ocasiones, citando a Cioran, en la última entrega de sus diarios (Sánchez Robayna, 2016: 257):

Esta mañana, inesperadamente, y con más claridad que nunca, el reconocimiento de una arraigada verdad íntima expresada en palabras de asombrosa justeza: "Mientras tenemos el sentimiento del misterio, conservamos implícitamente una dimensión religiosa. Pues ser religioso es sentir el misterio, incluso fuera

\footnotetext{
${ }^{6}$ Cfr. Sánchez Robayna (2016: 291): «En el correo, carta de Salah Stétié. "Vous êtes un poète du réel et cela est essentiel à mes yeux". Cuánto me ayudan a comprenderme estas palabras, a ver desde fuera (si esto es posible, o al menos ver con otros ojos) algo que tal vez sólo llegamos a intuir. En este caso, creo que no resulta, sin embargo, demasiado difícil percibir la cerrada materialidad de la visión, o quizás mejor la percepción de la presencia, la inmediatez de lo visible, la corporalidad, en suma, del mundo.»

7 Otto (1985: 40) lo califica como «lo heterogéneo en absoluto, lo thateron, anyad, alienum». Podríamos decir «totalmente otro».
} 
de toda forma de fe" (Cioran, Cuadernos). No deja de ser significativo el que sea Cioran -precisamente Cioran- quien tenga que recordar a muchos «materialistas» estas cosas.

Este principio es tan crucial en la obra del poeta, que llega a cifrar en él su diferencia decisiva con respecto a Valéry afirmando que «el sentimiento del misterio es precisamente lo que otorga al ser humano su humanidad» (Sánchez Robayna, 2016: 262). El conocimiento que busca la poesía es un saber del misterio, o «misteriosofía» (Sánchez Robayna, 2011a: 13), que parte de lo material para llegar a una epifanía. Es este un dato esencial, como veremos, en la concepción sacramental del poeta canario: en la carnalidad del mundo, en su materialidad, late el misterio. ¿Y no es 'mysterium' la forma latina derivada del griego 'mysterion' que designa los cultos mistéricos? El propio poeta se asombra de la convergencia entre ' $m y \hat{o}$ ' («cerrar los ojos» para la iniciación, origen del término 'místico') y su poema «Abril», señalando la vinculación genética entre 'mystês', «iniciado» y 'misterio' (Sánchez Robayna, 2016: 100-101). No ha de extrañarnos que el final del poema recuerde las técnicas de meditación en las que se cultiva la actitud contemplativa mediante la entrega a la percepción de la naturaleza, sin otra intención. Al cerrar los ojos, el contemplador se pone por entero en lo contemplado y asiste al nacimiento de los objetos en la luz. Esta llamada unifica lo interno y lo externo (el aire se ha percibido fuera, pero se encuentra dentro) y se concreta (no lo olvidemos) en una obra de arte que, nuevamente, convoca al contemplador, el poeta que escribe (2003: 343-344): «Es abril. Es el aire / que corre, y que nos lleva. / Es el aire allá adentro: / en los ojos cerrados. [...] // Cierra ahora los ojos. / Óyelos. Oye el aire / de abril correr allá, / sobre el fulgor del mundo» ${ }^{8}$.

No se llega al misterio separando lo material, sino profundizando en la materia a través de la palabra o, por decirlo de otro modo, en las bodas de la materia con la palabra. El poeta no puede, sin embargo, acceder por su propio pie al misterio, trascendencia que siempre lo supera: por ello el poema se transformará con frecuencia en oración o petición: «Armonía del mundo, dame el misterio último de la isla no hallada» (2010: 25).

Esta concepción presupone una teoría de la inspiración que no podemos desarrollar en este trabajo, pues «la palabra verdadera, la que parece brotar como por milagro, lo hace desde una región en que remotísimos magmas (de la memoria, de la reminiscencia verbal, del inconsciente, de lo desconocido)» (Sánchez Robayna, 1995: 350). Solo de este modo, mediante una palabra que no es instrumentalizada por el escritor, puede convocarse la presencia en «una convocación que, en rigor, no se aparta en ningún punto del sentimiento y la experiencia de lo sagrado». Es necesario aclarar, en todo caso, que esta idea de la palabra poética como palabra inspirada no anula en ningún momento el pensamiento del poeta (se trata de un 'no-hacer' activo). Partiendo de una afirmación de Wallace Stevens («Las concepciones son artificiales. Las percepciones son esenciales»), señala Sánchez Robayna (2008a: 327) cómo la poesía ha de deshacer, en una tarea crítica propia del pensamiento poético, todos «los preconceptos, las conceptualizaciones que son falsificaciones de la realidad

\footnotetext{
${ }^{8}$ En efecto, como nos ha indicado el propio autor, el poema «Abril» está muy ligado a la pintura de Albert RàfolsCasamada que lleva el mismo título. El poema se publicó en un pliego con motivo de una exposición de Ràfols en Las Palmas de Gran Canaria en 1998, pliego en el que se reproduce igualmente la pintura.
} 


\section{Tropelías. Revista de Teoría de la Literatura y Literatura Comparada, 29 (2018)}

Alianza y comunión: la poesía como sacramento en la obra de Andrés Sánchez Robayna

visible y que provienen de una razón autosuficiente y omnímoda». Se trata de un movimiento ascético, de cuestionamiento incesante, de despojamiento continuo del yo, que permite la verdadera escucha ${ }^{9}$ y abre espacio a la revelación, la «aparición de una realidad nueva, desnuda, despojada de todas las capas con que la recubren la razón y la ideología» (2008a: 327). Lógicamente, este cuestionamiento es una interrogación continua a la palabra (como sabemos, uno de los pilares que sostienen y cohesionan la obra del poeta desde su inicio).

De este modo puede reunificarse lo visible con lo invisible (sombra y apariencia) y en este sentido puede entenderse el arte como sacramento: una palabra eficaz se une al mundo y lo transfigura, penetrando en su misterio; el poeta y el lector comulgan con la carne del verbo -la sonoridad cargada de sentido de la palabra poética, pues la poesía es «carne significante» (Sánchez Robayna, 2016: 320)-, de modo que participan de este misterio. El sacramento es símbolo: al tragar lo visible, se traga también lo invisible. Por ello nos movemos en una poética de estirpe simbolista (Sánchez Robayna, 2016: 296-297). No en vano, los conceptos visible e invisible recuerdan vivamente la obra de Juan Ramón Jiménez ${ }^{10}$, así como el proyecto de completar lo visible con lo invisible, unificando ambas dimensiones.

La trascendencia late tras todo lo visible, siendo tarea del poeta llevar toda la realidad a la unidad. Por ello, cualquier escena o situación cotidiana puede transfigurarse, mostrando su fondo misterioso, como observa el poeta al contemplar el cuadro de Velázquez El aguador de Sevilla (Sánchez Robayna, 2015: 30):

Una escena corriente de la vida diaria sufre, sin embargo, una notable trasformación, y la dignidad se transmuta en sacramentalidad. [...] El espíritu de nobleza y gravedad con que la luz reviste a los personajes, lo mismo que la zona de sombra en que mantiene al hombre que bebe, configuran un ámbito mistérico. Y aquello que define al misterio es precisamente lo que escapa a toda explicación, a toda racionalidad. Ámbito de lo secreto, de lo arcano. El paso a lo sacramental se da con toda naturalidad, es decir, con los caracteres aparentemente insignificantes de una escena cotidiana.

La obra de arte, al unir palabra espiritual y realidad, transfigura ésta en un espacio sagrado ${ }^{11}$, en un centro que atrae al espectador o lector (la admiración que causa lo sagrado), al tiempo que procura unificarlo con el mundo. Como observaba Rudolf Otto, lo sagrado es principio activo que sale al encuentro y toma la iniciativa para traer a sí y transformar al hombre; la belleza es llamada que suscita el deseo y unifica (según el juego de palabras platónico kalós/kalléin). Por ello la imagen del vaso de agua puede servir como símbolo del poema («el vaso de agua es el poema mismo» (Sánchez Robayna, 2015: 71)), al reunificarlo todo en su transparencia y simplicidad (Sánchez Robayna, 2015: 72):

Pero no se conforma con eso [con aspirar a la corporalidad misma del vaso]: quiere también su manera de «aclarar» el mundo. Busca, además, extraer del vaso, o tal vez solamente compartir con él, la

\footnotetext{
${ }^{9}$ Sobre la poesía de Sánchez Robayna como escucha, cfr. Gómez Montero (2012: 178-185).

${ }^{10}$ Cfr. «Poesía y pensamiento» (Sánchez Robayna, 2008a: 325).

${ }^{11}$ Cfr. Sánchez Robayna (1996: 241): «"Donde acaba el lenguaje empieza, no lo indecible, sino la materia de la palabra”, escribe G. Agamben. Movimiento litúrgico, movimiento que ha hecho posible la transfiguración del mundo, la transubstanciación. Fin del lenguaje: nacimiento de la palabra».
} 
paz que lo envuelve (y la pacificación que genera), la pureza de su materia (y la purificación que parece crear a su alrededor). Quiere ser contemplado como centro. Aspira a su profunda simplicidad. Busca, sí, como el vaso, dar cuerpo o forma al alma perdidiza. Y poder ofrecer las palabras como un gesto de entrega, un acto sacro o sacramental que va hacia el Otro como una obra de amor. Sólo de esta manera podrá el lenguaje al fin cumplirse, no ya en sí mismo, sino fundido con el espíritu. [...] Sólo de esta manera, en fin, podrá decir, con Juan Ramón Jiménez: «La transparencia, dios, la transparencia».

Subraya este texto un aspecto que no había aparecido hasta el momento: el poeta es el oficiante de un oficio litúrgico que se entrega a sí mismo al entregar su palabra. El vaso de agua no es sólo el poema, también es el poeta que ha de vaciarse para contener el mundo dentro y unificarlo en la palabra que da origen al poema ${ }^{12}$. En este sentido, puede decirse que el poeta es también oficiante de la liturgia y víctima del sacrificio que el acto poético supone. El vaciamiento del poeta (que vimos ya en el comentario a la cita de Wallace Stevens) provoca la unificación de realidad (objeto) y sujeto en la palabra ${ }^{13}$. Y este proceso de vaciamiento o desposesión del yo (sacrificio o muerte del mismo) se entrega en el poema al lector que, como en la cadena que forja la piedra Heraclea del Ión, puede por el amor entrar y unificarse también en el poema, si (hermenéuticamente -en la medida en que la lectura poética es ya interpretación-) es capaz de vaciarse para acoger la palabra.

Observamos una concepción poética similar a la señalada por Jean-Pierre Richard para Mallarmé y comentada por el mismo poeta (Sánchez Robayna, 1998: 14) ${ }^{14}$ :

Mallarmé hará de este hallazgo [de la Nada], de este drama, una liturgia. Es su saber negativo, la construcción poética que sustituye a Dios, que ocupa su lugar. Saber hacer hablar a esa Nada. Con razón ha escrito Jean-Pierre Richard que el "instinto espiritualista" de Mallarmé "consigue reemplazar la perspectiva religiosa tradicional por la de una suerte de humanismo trascendental del cual él mismo sería el oficiante, el altar y el testigo".

Se trata de una apropiación en el ámbito de lo inmanente de una categoría propia de la liturgia cristiana (Cristo como sacerdote, víctima y altar), en consonancia con el proyecto moderno, como ha observado Abrams en la corriente que lleva de Wordsworth a Stevens y a la que califica de «Sobrenaturalismo natural» (1992: 52-57). Ciertamente esta concepción sagrada de lo poético llama al poeta a entender su vida como vocación y consagración a la poesía, que es y ha sido todo para el poeta «literalmente y en todos los sentidos» (2016: 174).

Es necesario comentar cómo Sánchez Robayna subraya en el texto anterior la importancia en esta liturgia del amor: «Y poder ofrecer las palabras como un gesto de entrega, un acto sacro o sacramental que va hacia el Otro como una obra de amor» (2015: 72). El vaciamiento no es un impulso de muerte o autodestrucción, sino que se realiza llevado por el deseo del Otro, como entrega

\footnotetext{
${ }^{12}$ Cfr. la célebre respuesta de Juan Ramón Jiménez al cuestionario de Juan Bertolí, publicado en La Prensa (Xirau, 1980: 33): «Cuando yo escribo, desaparezco por completo; no me siento siquiera, soy todo idea o todo sentimiento, todo palabra, todo nombre».

${ }^{13}$ Cfr. Sánchez Robayna (2011b: 14-15): «Por otra parte, el vaciamiento del yo está indisolublemente ligado a la unificación o reunificación (no dualidad) de sujeto y objeto. ¿No dijo un viejo pintor budista que nadie puede pintar una montaña sin haberse convertido antes en montaña?»

${ }^{14}$ Y que no está alejada de la concepción juanramoniana de lo sagrado (Xirau, 1980: 65): «Lo que es fundamentalmente sagrado en la poesía de Juan Ramón Jiménez puede reducirse a tres palabras: el Poeta, el Poema, la Obra».
} 


\section{Tropelías. Revista de Teoría de la Literatura y Literatura Comparada, 29 (2018)}

Alianza y comunión: la poesía como sacramento en la obra de Andrés Sánchez Robayna

hacia él y vía para alcanzar la unidad ${ }^{15}$. Este deseo del Otro es la raíz que une amor y poesía (la «razón unitiva» de la que habló María Zambrano, entrelazando mística, poema y misterio):

La raíz de la poesía es la misma que la del amor. La ciencia del amor se dirige hacia un objeto oculto. Lo secreto, el misterio. Tanto más hondo cuanto más misterioso. Tanto más hermoso cuanto más secreto. Cerrar los ojos. Ver ojos adentro. No conocemos lo amado. Por eso lo amamos (Sánchez Robayna, 2016: 492).

El vaciamiento del yo supone una liberación del temor ante la muerte, «el arte por antonomasia» (Sánchez Robayna, 2011b: 15), como manifiesta el autor al final de Deseo, imagen, lugar de la palabra, y por ello una liberación para quienes participan del movimiento de contemplación. En este sentido vincula el autor la experiencia poética con el sentimiento oceánico, al comentar la obra de Hulin, La mística salvaje (Sánchez Robayna, 2008b: 147), término que procede de Romain Rolland:

Y es aquí donde la poesía tiene mucho que decir: interesada por el misterio, atravesada por él, la palabra poética accede a veces a un territorio extremo en el que queda alterada la percepción del mundo y disuelto o anulado el pensamiento intencional y, por esa vía, conduce a la conciencia hacia el "sentimiento oceánico". E il naufragar m'é dolce in questo mare, dice el verso final de "El infinito" de Leopardi... Más aún cuando, al hablar del "resplandor" de la alegría mística, Hulin acierta a definir, de manera involuntaria, uno de los rasgos más característicos de la experiencia poética: "una verdadera licuefacción del pensamiento conceptual".

En efecto, Rolland describe el «sentimiento oceánico» como «el sentimiento religioso espontáneo, o, más exactamente, la sensación religiosa que es completamente diferente de las religiones propiamente dichas... el hecho simple y directo de la sensación de lo Eterno» (Hulin, 2007: 24). Este aspecto, que puede ser relacionado con la dimensión «fascinante» de lo numinoso según Otto (1985: 51-54), tiene importantes resonancias en la obra de Sánchez Robayna, pues se asocia a su condición insular, ya que la presencia envolvente del mar provoca con más facilidad esta sensación religiosa.

Continuamente nos remite el autor a lo religioso previo a las religiones (en el sentido de la fenomenología de la religión cuyo origen se encuentra en Otto, según vemos). Cabría preguntarse qué sentido tiene, por tanto, lo religioso en la obra de Sánchez Robayna, aun sabiendo que no podremos alcanzar una respuesta plenamente satisfactoria, ya que el propio poeta considera «la tarea más comprometedora y urgente [...] una redefinición de lo religioso», «pues muchas de las experiencias de mística salvaje (aconfesional, no teísta) [...] son, en el sentido más estricto, religiosas, aun cuando hayan estado al margen de toda forma de fe» (Sánchez Robayna, 2008b: 148).

\footnotetext{
${ }^{15}$ Cfr. el siguiente apunte recogido en el reciente volumen de su diario (Sánchez Robayna, 2016: 305): «En unas páginas inéditas de María Zambrano («Notas del Café Greco», 1958) leo: «El triunfo final de la vida, de lo viviente, depende, pues, de llegar a un medio enteramente vivo a su vez; a no darse en la muerte, en lo muerto. (De ahí que la mística de todas las religiones consista, más o menos declaradamente, en vivir y respirar en el amor y sólo en el amor.) Pues que el amor es la esencia de la vida».
} 
Esta redefinición de lo religioso se orienta en la línea marcada por Rudolf Otto, desde la concepción del misterio y (en el caso de nuestro poeta) la experiencia de lo fascinante, que encuentra un correlato no del todo inexacto en la idea estética de lo bello (Sánchez Robayna, 2008b: 148-149):

\footnotetext{
Queda pendiente, eso sí -en la línea abierta por el clásico libro de Rudolf Otto sobre lo sagrado-, una redefinición de la experiencia religiosa en el sentido de Einstein ("El misterio es lo más hermoso que nos es dado sentir. [...] En ese sentido, y sólo en él, pertenezco a los hombres profundamente religiosos"), que es también, en el fondo, el sentido de la mayor parte de los ejemplos aquí aducidos e interpretados.
}

En efecto, en Sánchez Robayna será frecuentemente la belleza, lo 'mirum' la fuente de atracción que llame y reúna al contemplador, en un doble éxtasis erótico: salida de sí de la belleza que llama al que la contempla (como en Platón) y éxodo del contemplador que entra y se une con lo contemplado $^{16}$. Esta estructura tiene su base en la noción de religación, ya mencionada anteriormente. Para Zubiri (1984: 128-130), el hombre solo puede vivir y ser apoyándose en «el poder de lo real», al que se encuentra religado: no se trata de un sentimiento o de una vinculación, sino del fundamento de la vida del hombre, un hecho total que afecta toda su realidad (desde lo más físico a lo más espiritual), la raíz de su ser. Para Zubiri (1984: 129), «la religación es "la estructura respectiva" misma en que acontece el poder de lo real», por lo que no solo es humana sino también cósmica. Zubiri concibe a Dios como «fundamento del poder de lo real», más allá del ser, pues «Dios no tiene ser». Si sustituimos esta idea de Dios por el vacío o la nada positiva de ciertos filósofos budistas, tal vez no estemos demasiado lejos de la relación con lo sagrado en Sánchez Robayna.

En su obra, el sentimiento de pertenencia a la tierra se vuelve acuciante (especialmente ante la conciencia de la muerte): «¿No somos hijos de la sal, no somos / tuyos, no somos tú?» (Sánchez Robayna, 2004: 205). Identidad con la tierra, conciencia de formar «un todo con la tierra» (1995: 351) que se concreta en el «sentimiento del lugar». Esta noción, de estirpe zambraniana, es de carácter eminentemente sagrado (Zambrano, 2007: 48) y remite al lugar de origen, que en el caso del poeta canario se une a la insularidad, símbolo plurisignificativo pero que está preñado (según hemos visto) de sentimiento oceánico por la dialéctica entre finitud e infinitud ${ }^{17}$. Recuerda este pertenecer a la tierra la filosofía heideggeriana de la Cuaternidad (Heidegger, 1994: 131) en la que tierra y cielo, divinos y mortales forman una unidad y se pertenecen, más aún si tenemos en cuenta cómo la obra de arte establece un mundo y hace la tierra (1958: 81). Sin embargo, hay que resaltar varias diferencias, entre las que no son las menores la falta de proporción entre la tierra y el hombre (éste pertenece a aquella), al igual que entre la isla y el océano que la circunda (símbolo de la relación ente-ser, hombre-misterio), así como el fundamento erótico que preside la relación con la tierra (según veíamos antes). Habría de asociarse por tanto, más que a la tierra heideggeriana, al concepto de naturaleza que el filósofo expone en «Como cuando en día de fiesta», que se muestra con el doble

\footnotetext{
${ }^{16}$ No falta, tampoco, el rostro «tremendo» de lo divino en la obra de Sánchez Robayna, desde los «vórtices negros» de «Cifra del arrecife» (Sánchez Robayna, 2004: 74), a la «mano atronadora» de «Luz de Fuerteventura» (Sánchez Robayna, 2004: 205), o al «lugar de encuentro con el comienzo de lo terrible» (2010: 119).

${ }^{17}$ No se trata, como el poeta quiere dejar claro, de un espacio concreto, sino del «espacio que metaforiza y resume, en realidad, todo espacio» (Sánchez Robayna, 1995: 352).
} 


\section{Tropelías. Revista de Teoría de la Literatura y Literatura Comparada, 29 (2018)}

Alianza y comunión: la poesía como sacramento en la obra de Andrés Sánchez Robayna

rostro de lo sagrado según Rudolf Otto: omnipotente y «divinamente hermosa» (Heidegger, 2005: $59)^{18}$. Se trata de la $\square y$ sis, como «surgir y salir afuera, [...] un abrirse que, al eclosionar, al mismo tiempo retorna al surgimiento y, de este modo, se encierra en aquello que en cada ocasión le otorga la presencia a lo que se presenta» (2005: 63).

Este salir de sí, desapropiándose y ocultándose en el misterio, se apropia del poeta, que se asombra y presta oído a la palabra que comparece ante él. En efecto, el poema se muestra como una «auscultación del lugar» (Sánchez Robayna, 1995: 351) que procede del deseo (el cual abre el espacio como la obra en Heidegger despliega un mundo): de ahí que el espacio contenga al hombre $\mathrm{y}$, sin embargo, se suscita o despierta en él, ya que es el hombre quien lo abre (reinterpretándose tal vez la co-pertenencia heideggeriana).

Como en los griegos, la belleza del lugar suscita el canto de celebración, pues -nos recuerda Heidegger en «Memoria» (2005: 149)- «la belleza es la presencia del Ser». No debemos entender aquí belleza en el sentido de proporciones o formas agradables sino en el de apertura del misterio (que se entrega sin dejar de ser trascendente y enigmático), huella o traza en unos casos, luz cegadora en otros de lo que trasciende, que sin embargo parece abrirse al hombre. De ahí la importancia que el paisaje desnudo, la tierra calcinada o desierta pueden tener en la obra de Sánchez Robayna (así como el símbolo de la luz -en nuestro autor hay toda una teología de la luz- en el que no nos podemos detener).

El canto celebra, como afirma el poeta en «Poesía y pensamiento» (Sánchez Robayna, 2008a: 316-317): «La palabra poética, en efecto, celebra lo existente, en los diversos sentidos de la palabra celebrar: conmemorar, oficiar, alabar. "¿Y por qué el silencio te conoce, y el furor, así como la estrella y la tempestad? -Porque yo celebro”, dicen las conocidas palabras de Rainer Maria Rilke». Dentro del «Sobrenaturalismo natural» en el que esta poética se inserta, la celebración, la alabanza, la conmemoración (términos todos religiosos) se dirigen a la tierra, de manera que los rasgos de lo divino han sido absorbidos por la naturaleza (como señala Abrams). Esta concepción se encuentra nuevamente en consonancia con el comentario que Heidegger (2005: 66) realiza de Hölderlin en «Como cuando en día de fiesta»: «Lo sagrado es la esencia de la naturaleza, que desvela su esencia en el despertar en cuanto aquella que amanece».

Asistimos a un movimiento de invocación que se concreta en el deseo del poeta que se proyecta sobre una tierra precisa (el amor a un lugar) que de este modo lo atrae y suscita el canto que llama a la presencia para que se revele a través de las palabras:

Una convocación de la presencia... El poema representa un oscuro o tentativo movimiento del ser y del espíritu hacia lo que no se posee, hacia la posibilidad de la presencia y de la posesión por la imagen.

\footnotetext{
${ }^{18}$ Cfr. Heidegger (2005: 59-61): «La esencia del poder se determina a partir de la omnipresencia de la naturaleza, a la que Hölderlin llama «la poderosa, divinamente hermosa». [...] Si recibe el nombre de «hermosa» es porque está «maravillosamente omnipresente». Que su presencia sea total no significa que abarque completamente todo lo real desde el punto de vista de la cantidad, sino que domina incluso a aquellos elementos reales que de acuerdo con su modo de ser parecen excluirse mutuamente. [...] La naturaleza omnipresente cautiva y sustrae. [...] La belleza es la omnipresencia. La poderosa, porque divinamente hermosa, porque maravillosamente omnipresente, la naturaleza abarca y abraza a los poetas. Están inscritos en ese abrazo. Estar allí inscritos sitúa a los poetas en el rasgo fundamental de su esencia.»
} 
Esa imagen se sitúa, sin embargo, en la linde de lo real o de lo visible como punto desde el que acceder a lo invisible. Pues sólo la realidad -nuestra inmersión en lo real- puede, ciertamente, llevarnos a lo que está más allá de ella. Poco sentido tendría para nosotros la aprehensión de lo puramente invisible sin conexión alguna con nuestras realidades y nuestros mundos concretos. Lejos de las puras creaciones de lo imaginario desustanciado de toda realidad, de toda temporalidad, el poema es o representa un movimiento de religación de temporalidad y eternidad, de palabra y mundo, de realidad visible y realidad invisible. Pues la palabra poética, ¿no nos invita, en verdad, a la parusía, esto es, a la búsqueda de la presencia, al encuentro de lo sagrado en nuestro mundo? ¿No es el logos poético, en su más honda raíz, una metáfora de la encarnación, logos que traduce el mundo y es el mundo?

En efecto, el poema brota movido por el deseo de lo desconocido, es una inmersión en el misterio, pero misterio que es el fondo invisible de lo visible («como un hueso semillero en la carne de su fruto», por emplear las palabras de Juan Ramón): poética simbolista que encuentra en la materia lo sagrado, reunión de lo material y lo espiritual ${ }^{19}$. Al enlazarse la realidad con la imagen (imagen-símbolo - que procede de unos estratos que el hombre no domina, pues son anteriores a él ${ }^{20}$ ), esta encuentra permanencia, se funda en lo permanente ${ }^{21}$, alcanza (o es alcanzada por) lo sagrado. De ahí que pueda hablarse de una encarnación (nuevamente encontramos un concepto teológico apropiado para la función poética) ${ }^{22}$ : palabra que se hace carne o cuerpo, bodas de la palabra y el mundo (materia del lenguaje-materia del mundo), «palabra de transmutación y de transubstanciación ${ }^{23}$ » (Sánchez Robayna, 1996: 245). De este modo la palabra convoca una presencia (hay algo en lo que decimos) que toma cuerpo en la palabra; y al mismo tiempo este nombrar se ahonda en lo invisible, unificándolo con lo visible. En este sentido podemos entender la cita que encabeza el presente artículo (Sánchez Robayna, 2016: 485): «Sacrificio (sacrum facere). Todo poema es una operación sacrificial. Aspira a hacer sagrado aquello que ha podido tocar con la palabra». Por ello puede afirmar el poeta la vinculación entre poesía y oración (Sánchez Robayna, 2016: 483).

Comprobamos en la cita nuevamente cómo Dios ha sido sustituido por la realidad, que es creada (como en Juan Ramón) en el acto poético ${ }^{24}$. Por otra parte, podríamos pensar que hay una contradicción entre la poesía como revelación (otra realidad que irrumpe) y esta creación del objeto

\footnotetext{
${ }^{19}$ Se trata de llegar al «ser más real», que según Rudolf Otto (1985: 35) es uno de los signos de lo sagrado. Es necesario recoger en este punto la cita de Simone Weil que Sánchez Robayna (1985: 117) incluye en su ensayo «En el texto de María Zambrano»: «La escritura regresa a sí misma apenas ha tocado su objeto. Pero ese objeto es muchas veces inasible, está oculto o escondido como el ser está escondido en lo humano; en este sentido deben recordarse unas palabras de Simone Weil: lo que está escondido es más real que lo que se manifiesta, y esto es verdad en toda la escala que lleva de lo menos escondido a lo más escondido. Como sus objetos, en fin, palabra de María Zambrano está, asimismo, oculta: es un germen o una semilla, una latencia que habrá de manifestarse, en efecto, pero que ha de hacerlo sólo como revelación.»

${ }^{20}$ Aunque puede manipular, de ahí la importancia de una moral de la imagen, como señala el autor.

${ }^{21}$ Cobra aquí especial significación el concepto de mito de Valéry (Sánchez Robayna, 2002: 30): «Mito es aquello que no existe ni subsiste más que por la palabra» (P. Valéry, «Pequeña carta sobre los mitos», 1928). Ninguna aproximación más nítida y certera a la idea de mito, siempre que se recuerde que la palabra del mito es la palabra poética, es decir, la palabra recorrida por la imagen. Mito - podría tal vez decirse, sin alteración esencial de la idea de Valéry- es aquello que no existe ni subsiste más que por la imagen.»

${ }^{22}$ Ya en Juan Ramón Jiménez (cfr. la carta a Ramón Gómez de la Serna, en Blasco, 1981: 142) esta noción se desarrolla en María Zambrano y llega a José Ángel Valente.

${ }^{23}$ Obsérvese la terminología propia del sacramento eucarístico.

${ }^{24}$ Cfr. Blasco (1981: 149).
} 


\section{Tropelías. Revista de Teoría de la Literatura y Literatura Comparada, 29 (2018)}

Alianza y comunión: la poesía como sacramento en la obra de Andrés Sánchez Robayna

de la que habla la cita anterior. Sin embargo, no debemos olvidar la teoría de la inspiración que subyace: no hay intencionalidad ni ejercicio de la voluntad (la imagen procede de un fondo más allá de la conciencia); el fin del poema es la unificación (el arquero ${ }^{25}$ ha de unificarse con el blanco, es él mismo el blanco). Por ello el texto no sostiene que el poeta pueda crear la realidad, sino el poema (la obra $)^{26}$. Podríamos afirmar que el poema crea el objeto, o mejor, lo construye en el sentido del «bauen»: crea un espacio vacío, abre un espacio, en el que el hombre puede entrar, morar y habitar en contacto con lo sagrado. Por ello «poetizar, como dejar habitar, es un construir» ${ }^{27}$ y en esta obra se revela lo oculto sin dejar de ser misterio ${ }^{28}$.

Este construir y habitar la imagen-cuerpo del mundo mediante la obra poética, esta encarnación en la palabra de lo visible y lo invisible del mundo, cuya carne comulgan lector y poeta, constituye una liturgia que reúne a los hombres y lo sagrado, al mundo y lo sagrado. La alianza tiene lugar en el símbolo-imagen, que unifica lo escindido ${ }^{29}$ y es el cimiento de la liturgia. El poema posibilita la resacralización de la tierra, la devuelve a su ser, de modo que la tierra puede volver a ser «lugar de encarnación» ${ }^{30}$. La poesía reactualiza así la acción cultual de los orígenes (Taubes, 2007: 286):

Cuando un pueblo llega por primera vez a un territorio, esta tierra está oscura y vacía y los cielos que la cubren están cerrados hasta que se instala el culto. El territorio es la base del culto, pero la tierra era suelo neutral hasta la instalación del culto. Sólo cuando se practica el culto, la tierra cobra vida y los cielos se abren como un firmamento sobre ella. [...] La primera acción sagrada es, por ende, el sacrificio de dioses por parte de los dioses y el de hombres, por parte de los hombres. Una vez que se ha ceñido el lazo entre los dioses y los hombres, puede concertarse la alianza del culto. La alianza es un símbolo absolutamente no metafórico. El «símbolo» es el contrato, la unión de las dos partes. El símbolo es signo de la alianza con la que los dioses demuestran su comunidad con los hombres.

Por todo ello la poesía es, al mismo tiempo, convocación de la presencia y encarnación de la palabra, aparición (y ocultación) de lo sagrado. Así se observa en «Como cuando en día de fiesta» (Heidegger, 2005: 84-85), en una concepción cercana a cuanto estudiamos:

La palabra de este canto ya no es un "himno a" algo, ni un himno "a los poetas", ni siquiera un himno "a la naturaleza", sino el himno "de lo" sagrado. Lo sagrado dona la palabra y viene él mismo en esa palabra. La palabra es el propio acontecer de lo sagrado. La poesía de Hölderlin es ahora un llamar inicial,

\footnotetext{
25 Se puede pensar en el poema LXXIV de El libro, tras la duna (Sánchez Robayna, 2004: 421-422) o en el texto «Meditación sobre el arquero» que escribió Sánchez Robayna en Cuadernos Hispanoamericanos (núm. 734, pp.11-17) en 2011 a propósito del libro de Herrigel, El zen en el arte del tiro con arco de 1948.

${ }^{26}$ Conviene apuntar aquí la similitud entre la conversión a la imagen (la sangre «vuelta imagen») indicada por Robayna (1995: 352) y el «hablar en imágenes» heideggeriano (1994: 149).

${ }^{27}$ En este sentido, puede leerse lo expuesto como no tan lejano de los célebres versos de «El nombre conseguido de los nombres» (Juan Ramón Jiménez, 1999: 267): «Si yo, por ti, he creado un mundo para ti, / dios, tú tenías seguro que venir a él, / y tú has venido a él, a mí seguro».

${ }^{28}$ Cfr. «[...] poéticamente habita el hombre» (Heidegger, 1994: 147-148): «el poetizar como sacar la medida de aquella extraña medida es algo que se hace cada vez más misterioso. Y así es como tiene que seguir siendo si es que estamos dispuestos a residir (a mantenernos abiertos) en la región esencial de la poesía».

${ }^{29}$ Sobre el símbolo «como revelación sensible y manifiesta de lo sagrado» que constituye una alianza, cfr. Trías (1994: 19).

${ }^{30}$ Cfr. Sánchez Robayna (1995: 352-353): «Y así, esa tierra del deseo, que es, debo insistir, la tierra toda, la naturaleza toda, se nos aparece como un espacio sagrado, un espacio que nuestra cultura ha debido abandonar y que es urgente redescubrir. Pues somos, como arriba se ha dicho, un todo con la tierra, un todo con nuestro deseo, cuya ruptura nos ha alejado infinitamente de nosotros mismos. La tierra desacralizada, que la palabra poética ha de saber resacralizar más allá de toda pérdida de la esperanza, espera de nosotros volver a ser un lugar de encarnación.»
} 
que llamado por lo venidero mismo dice a éste y sólo a éste como lo sagrado. La palabra hímnica es ahora producto de una "sagrada necesidad" y, por ser "sagradamente" necesaria, también es "sagradamente sobria". [...] La sobriedad es la permanente disposición fundamental de la predisposición para lo sagrado.

En efecto, lo sagrado pide un sacrificio que despeje el espacio, que desbroce un claro para la iluminación. Ese sacrificio («de dioses y de hombres» como manifestaba Taubes) es el vaciamiento de lo anterior (los ídolos, ideas o conceptos, retóricas o recursos a los que se aferra el yo), una desapropiación, una ascesis que puede manifestarse en sobriedad o pobreza estética del poema, que pide (en todo caso) un proceso de purificación de la palabra ${ }^{31}$, un sacrificio (Sánchez Robayna, 1996: 243):

Hay, en el poema, fases de meditación o contención, de sobriedad, según lo dijo Hölderlin. Para llegar hasta la orilla se ha recorrido el desierto; muchas veces, es sólo el desierto lo que, propiamente, se nos da. La infinitud de las arenas. Peregrinaje, soledad. Sacrificio.

Coinciden itinerario espiritual y estética ${ }^{32}$, pues se impone una poesía «en estado de sacrificio» (como ha observado María Zambrano de Lezama): «único estado en que el alma que contrae a diario nupcias con la realidad, se mantiene intacta: estado que pide y realiza la poesía ${ }^{33}$. Como expone María Zambrano en El hombre y lo divino, si la piedad es saber tratar con el misterio, el sacrificio es «la forma sagrada por excelencia» de trato (pacto o alianza) con ese fondo misterioso (1955: 208) y su saber propio es la inspiración, «saber desmedido» y arrebato que exige «una delicada medida». De ahí la importancia en este tránsito del «ritmo, el número y la música» (1955: 212), pues, como afirma la filósofa «el ritmo es rito» (Zambrano, 1955: 219) y la obra es «conjuro, invocación, decires [...] una forma de liturgia». Octavio Paz ahonda en esta asimilación entre ritmo y rito (1956: 62), asociando además el ritmo a la imagen, ya que el ritmo es «imagen y sentido», «imagen del mundo». Estas dos afirmaciones son cruciales para entender la concepción del rito en Sánchez Robayna, pues la invocación y la alianza se producen no exclusivamente mediante el símbolo-imagen sino también a través del ritmo, que es rito en su circular volver. Por una parte, el ritmo -nos dice Paz (1956: 63)por obra de la repetición hace regresar el mito (que, no lo olvidemos, Sánchez Robayna identificaba con la imagen); por otra parte, «la repetición rítmica es invocación y convocación del tiempo original» (Paz, 1956: 63), de modo que el ritmo funciona como conjuro contra el tiempo y la muerte (Sánchez Robayna, 2002: 133) ${ }^{34}$ que pretende regresar al origen, al tiempo arquetípico (de Eusebio, 2015: 56): «Todo poema aspira, en cierto modo, a esa paradoja que usted menciona, a romper la

\footnotetext{
${ }^{31}$ Cfr. Sánchez Robayna (1996: 245): «Tal fundamento metafísico me parece constituir el sentido de la crítica que, en mi escritura, ha recibido el lenguaje en sus aspectos más puramente sonoros o materiales, en los momentos en que el lenguaje debía, sí, purificarse, si se aspiraba a que palabra y mundo alcanzaran la unificación».

32 Cfr. Sánchez Robayna (2016: 139): «Pobreza es, en arte, intensidad, hondura. Ésa es su rara, paradójica riqueza. Siempre me han gustado los poetas (y los artistas) ascéticos. En un doble sentido: aquellos que buscan el perfeccionamiento espiritual y, de manera inseparable, tratan de desnudar o despojar su expresión».

33 En «La Cuba secreta» (Zambrano, 1996: 111). Sánchez Robayna (1996: 157) ha vinculado «la idea del sacrificio rilkeano» a los contenidos y valores de lo sagrado en poesía.

${ }^{34}$ Una aplicación de la vinculación entre ritmo y rito en Sánchez Robayna puede encontrarse en Peinado (2010). Lógicamente, el ritmo ha de entenderse en un sentido amplio, que abarca fenómenos no sólo fónicos sino también sintácticos. En palabras de Benjamin Hrushovski, «the rhythmical aspect of a poem implies the whole impact of the movement of the language material in the reading of a poem» (Domínguez Caparrós, 2010: 57).
} 


\section{Tropelías. Revista de Teoría de la Literatura y Literatura Comparada, 29 (2018)} Alianza y comunión: la poesía como sacramento en la obra de Andrés Sánchez Robayna

contradicción, a diluir el tiempo sucesivo y alcanzar el tiempo mítico originario». Ciertamente, para el poeta canario (Sánchez Robayna, 2016: 391), «la poesía, como arte musical que es, se funda en la repetición. [...] Repetición como instauración». En su obra asistimos a la continua meditación en torno a la tierra y a unos pocos símbolos a ella ligados (el mar, la luz), esperando que se produzca la encarnación de la palabra.

\section{«La alianza»}

Para concluir la presente investigación, puede resultar iluminador un breve acercamiento a «La alianza», poema perteneciente a La sombra y la apariencia. En «Inicial, o fracturas de una invitación imperiosa», se intercalan poemas cuya meditación surge de la contemplación de la naturaleza junto con otras composiciones que parten de un encuentro con un espacio artístico. Dos de estas composiciones, «La alianza»y «Capella Cornaro», que precisamente ocupan el centro de esta sección, desarrollan (precedidas -no lo olvidemos- del poema «Blinky Palermo») el espacio artístico como lugar de aparición de lo sagrado. No deja de resultar significativo, si consideramos estas tres composiciones un tríptico, que la pieza central (cuyo título contiene la poética de la religación de la que hemos hablado en estas páginas) se componga a su vez de tres partes.

El poema parece partir de una visita al Museo Morandi que, no en vano, se califica en Mundo, año, hombre como «peregrinación» (Sánchez Robayna, 2016: 287-288), pues ante un espacio sagrado nos encontramos ${ }^{35}$ :

MUSEO MORANDI. Pocos lugares como éste prefiguran (configuran) un peregrinaje. Aquí están no sólo muchas de sus obras, sino también su estudio reconstruido, los cacharros que pintó durante años, los cuadros - muy pocos, y ninguno moderno- que poseyó en su casa. Ninguna vida más ascética. (...) Es ya emocionante encaminarse hacia él, acariciar la tensión de esa espera. [...] Viejo temblor de las cosas, de los objetos polvorientos, de las flores que acaban pareciendo de papel o de tela. Colores pastel trabados en un infinito intercambio de formas que parecen fijarse para siempre. [...] Las sombras de botellas y de vasos. Y, al fin, botellas y vasos ya sin sombra alguna. En el estudio reconstruido, o más bien reproducido con exactitud en la forma en que fue encontrado, reposa el último cuadro, sin terminar, junto a sus cacharros. Imagino al pintor deambulando entre estos objetos -la mesa, la tela, la pared, la soledad, los pasos silenciosos, mortecinos. Pienso en su mirada y ésta me es devuelta por las telas con idénticos motivos: obsesión que renace apenas terminado un cuadro, y que renacerá una vez terminado este otro, en cadena que parece no tener fin. Pero lo tiene: ahí está la última tela (una Natura morta más), con su nuevo temblor asomando en formas inconclusas. Corría 1964.

«La alianza» surge de esta atmósfera y parece recrear los últimos momentos de la vida del $\operatorname{artista}^{36}$. Se compone de tres fragmentos: el primero se centra en la relación entre el pintor y el objeto, mientras se traza el cuadro; el segundo fragmento evoca la relación entre la obra y el mundo (mientras el artista se aleja); en el tercero, la relación entre obra y espectador ocupa el primer plano. Parte el primer fragmento de la atmósfera del estudio del pintor (en la que lo imagina, como en el fragmento anterior del diario se observa, en el momento de pintar): la creación surge de la contemplación de los objetos concretos (es una inmersión en la materia a partir de los cuerpos

\footnotetext{
${ }^{35}$ Para Sánchez Robayna (2016: 475) todo espacio verdaderamente artístico es religioso.

${ }^{36}$ Recuerda vivamente, en este sentido, «El pintor» (Sánchez Robayna, 2004: 357).
} 
reales), por ello comienza el poema con los motivos que una y otra vez cerca Morandi (igual que Sánchez Robayna gira en torno a los símbolos atlánticos), que son continentes, espacios vacíos para llenarse de otro: «una botella, un vaso». Las «gafas» nos recuerdan la mirada, pero también la separación (quizá la mediación y el límite que separa el sujeto y el objeto contemplado). Por ello, el comienzo del poema parece marcar la dualidad inicial, que será superada en «la alianza», así como el primer paso para lograr esta unidad: el abandono. Así se observa en el poema (2010: 29):

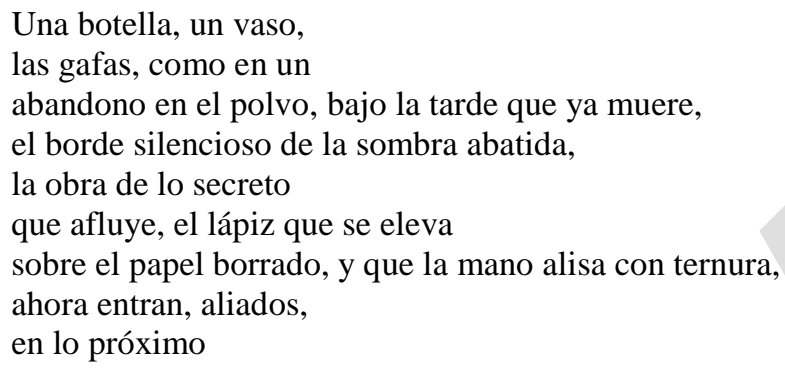

El abandono recuerda aquí el concepto heideggeriando de 'Gelassenheit', que puede traducirse antes como abandono que como 'serenidad' (Gutiérrez Pozo, 2003: 169). El artista, en efecto, ha de liberarse de toda voluntad de poder para dejar ser al objeto lo que es, para liberar las cosas en su verdad (Gutiérrez Pozo, 2003: 167); el pintor ha de sacrificarse y vaciarse, «renunciar a sí como sujeto» (Gutiérrez Pozo, 2003: 168). Las gafas, ciertamente, son cristal, transparencia en que ha devenido el pintor vaciado de sí mismo para poder acoger al otro. Se produce aquí la primera correspondencia entre los recipientes-objetos (la botella, el vaso) y la transparencia del artista, que va a llenarse de lo que a su vez es otro continente. El pintor, de hecho, ha desaparecido: solo quedan las gafas (su mirada vuelta transparencia) y la mano. El polvo viene a simbolizar ese deshacimiento, que culmina en los últimos años de vida del artista (objetos y gafas se sitúan «bajo» la sombra de «la tarde que ya muere», en un ambiente de acabamiento), al tiempo que señala el valor de lo pequeño y lo sencillo, lo aparentemente insignificante o nada, en la que se puede revelar lo abierto («para venir a serlo todo...»-según rezan los «Versillos del Monte de Perfección»-).

La presencia de la sombra, que remite al fondo invisible de lo visible (La sombra y la apariencia -no lo olvidemos- es el título del libro) nos convoca al misterio que late tras la realidad ${ }^{37}$, «la obra de lo secreto». El juego de sombras y luces, como es sabido, desempeña una función fundamental tanto en las acuarelas como en los aguafuertes de Morandi. Se inaugura así un juego de correspondencias: el abatirse de la sombra o la obra «de lo secreto que afluye» (que parecen insinuar el descenso del misterio, su éxtasis o salida de sí hacia el hombre) encuentran respuesta en «el lápiz que se eleva» y «la mano que alisa con ternura», que implican el éxtasis del hombre y el cuidado («Sorge») amoroso hacia la realidad y su misterio (un ejemplo, más bien, de la «piedad» que, para María Zambrano, consiste en saber tratar con el misterio). No hay una relación técnica con la realidad, a través de la cual el sujeto produzca lo real, sino que «lo secreto» afluye, viene hacia el

\footnotetext{
${ }^{37}$ Cfr. el ensayo «Para una historia de la Piedad» de María Zambrano (1996: 129).
} 


\section{Tropelías. Revista de Teoría de la Literatura y Literatura Comparada, 29 (2018)}

Alianza y comunión: la poesía como sacramento en la obra de Andrés Sánchez Robayna

hombre, que ha de recibirlo y cuidarlo. De este modo se realiza durante el proceso creativo «la alianza» que da título al poema: como veremos, esta alianza aparece en cada fragmento del poema, aplicada a una relación diversa (en este caso, la realidad que se unifica con el pintor).

«Borde», «obra de lo secreto», «lápiz»y «mano», «entran, aliados / en lo próximo». Pero, ¿qué es «lo próximo»? Debemos observar cómo los co-ligados se encuentran separados por un encabalgamiento abrupto de «lo próximo». Lo próximo, lo que está cerca, se encuentra, no obstante, tras una cesura o gozne que separa en tanto que une. Es necesario percibir cómo esta estructura se repite en un curioso paralelismo (tres oraciones que concluyen con un adjetivo sustantivado), que se encuentra separado en encabalgamiento abrupto: «lo próximo», «lo abierto», «lo indivisible». Estos tres adjetivos sustantivados se hallan en relación y poseen un indudable sabor heideggeriano. El artista es aquel que (en una civilización en la que las personas cada vez están más volcadas a lo lejano, lo virtual) sabe estar presente junto a lo que le rodea. Estos objetos cercanos y concretos que llaman su atención comunican con «lo próximo». En relación con «lo abierto» y «lo indivisible», entendemos que «lo próximo» ha de evocar «la cercanía al origen» descrita por Heidegger en «Regreso al hogar» como «un misterio» ${ }^{38}$ que remite a lo inmediato, a lo abierto. Por ello, «el poeta llega a casa desde el momento en que en la cercanía llega al origen. Llega a la cercanía en la medida en que dice el misterio de la cercanía a lo cercano» (Heidegger, 2005: 29). Esta es la labor del poeta: atento a lo presente, dejándolo estar sin imponer su voluntad sobre ello, conduce y se conduce a lo próximo, donde lo distinto (el borde no desaparece) puede permanecer aliado y descansar en su esencia.

En la aproximación al objeto, el límite, que podría parecer división o barrera, se muestra como reflejo de «lo abierto» (concepto de estirpe rilkeana-heideggeriana que atraviesa todo el poema ${ }^{39}$ ). Todo objeto es una isla, pero precisamente el límite (que le da su estancia, su lugar o posibilidad de ser) lo abre a lo oceánico, lo in-mediato. Toda esta primera estrofa está dominada por el verso breve y los encabalgamientos (con frecuencia abruptos), que entrecortan el poema y, al tiempo que crean una atmósfera de silencio, subrayan la noción de límite ${ }^{40}$.

«El borde, en su temblor, es un comienzo» (Sánchez Robayna, 2010: 29). Este temblor del comienzo es el sentimiento de lo «tremendo» que Rudolf Otto cifra como huella de lo sagrado («mysterium tremendum et fascinans»), cuya potencia anonada a la criatura ${ }^{41}$. Así se puede observar en el poema «Llega a un lugar de encuentro con el comienzo de lo terrible» (2010: 119). El temblor

\footnotetext{
${ }^{38}$ Cfr. Heidegger (2005: 28): «La cercanía que ahora reina permite que esté cerca lo cercano, pero también permite al mismo tiempo que sea lo buscado y por ende lo no cercano. Normalmente entendemos la cercanía como la distancia más pequeña posible entre dos lugares. Pero aquí la esencia de la cercanía consiste precisamente en que acerca a lo cercano en la medida en que lo mantiene alejado. La cercanía al origen es un misterio.»

$39 \mathrm{Y}$ al que dedica un poema en este libro: «Lo abierto». En él el espacio aparecerá como «sol absoluto» (Sánchez Robayna, 2010: 121), de manera similar al final del poema «La alianza.»

${ }^{40}$ La silueta rotunda (sombreada levemente) es una técnica frecuente en Morandi, que se acentúa especialmente en las planchas de cobre.

41 «Yo, que soy polvo y ceniza», es la frase de Abraham (cuya simbología encontramos al inicio del poema) que sirve para ejemplificar este sentimiento (Otto, 1985: 31-33). Heidegger menciona este terror ante «lo inmediato» en «Como cuando en día de fiesta» (Heidegger, 2005: 80). En el ensayo de Valente «Sobre la operación de las palabras sustanciales» (2008: 302-303), hallamos también la relación entre borde, comienzo, sacralidad y huella de lo sagrado.
} 
es la huella de la presencia de lo inmediato (allí donde lo finito desaparecería), que es quien abre y hace posible el juego de relaciones (Heidegger, 2005: 68-69):

Todo elemento real aislado en todas sus relaciones es sólo posible cuando previamente la naturaleza concede el espacio abierto en el que los inmortales y los mortales y toda cosa pueden llegar a encontrarse. Lo abierto hace de mediador en todas las relaciones entre lo que es real. Lo real sólo consiste en esa mediación y, por eso, es algo mediado. Lo que llega a ser mediato de este modo es sólo gracias a la mediatez. Y por eso la mediatez tiene que estar presente en todo. Sin embargo, lo abierto mismo, que le otorga a toda relación y correspondencia el espacio en el que pueden pertenecerse, no procede de ninguna mediación. Lo abierto mismo es lo inmediato. Nada que sea mediato, ya sea hombre o dios, puede llegar a alcanzar jamás lo inmediato de modo inmediato.

La obra muestra la unión de lo mediato y lo inmediato, el objeto y lo indivisible, pues la iluminación la produce el objeto concreto que el artista lleva a la obra: «Pintor, una celebración, / una llama en tu objeto, / ilumina, en el polvo, lo indivisible». La investigación del artista es un ahondamiento en la realidad y la materia, no una separación de ellas. El símbolo final de la llama alcanza mayor fulgor al irrumpir en la breve estrofa final, precedida por una primera estrofa más extensa en la que se produce una composición del lugar (lo que el poeta ve, en la primera oración) y una meditación o ahondamiento en lo visible (las dos siguientes oraciones). Si la primera estrofa crea una atmósfera en la que reina la sombra, ahora estalla la llama del objeto. Se trata (Gutiérrez, 2003: 168) del «esplendor de lo sencillo» (die Pracht des Schlichten), la «fuerza inagotable de lo sencillo» (unerschöpfliche Kraft des Einfachen).

El segundo fragmento se inicia con un imperativo que invita al lector a entrar en la escena, a ser iniciado en el recorrido que ha realizado el artista, a entrar en la comunión y la alianza del grabado («Mira»), pues (De Eusebio, 2015: 53) «los ojos son, por así decirlo, el lugar de encuentro del espíritu y el mundo, de espíritu y realidad visible». Este segundo fragmento es una celebración de la obra de arte, como se observa en la estructura, sustentada en los vocativos que se encuentran en una repetición circular quiasmática (basada en el oxímoron luz-volumen): «Oh volumen de luz», «Oh cuerpo de una alianza», «Oh luz voluminosa» (Sánchez Robayna, 2010: 30-31). Precisamente la unidad entre la obra y la naturaleza (la obra que da cuerpo a la naturaleza) lleva a la confusión al lector, que inicialmente quizá no consiga ver que se está describiendo un aguafuerte de Morandi: la plancha de cobre, al tocar la hoja de papel enlaza los seres de la naturaleza, que fuera de la obra parecen separados. En efecto, en el arte la realidad se vuelve un cuerpo (incluso la luz se torna «masa pura») en el que las correspondencias de la naturaleza se revelan, hasta el punto de que sombra y luz son ya inseparables en su mutuo corresponderse: «Oh volumen de luz, casi igual que la sombra invitadora, / pero ya masa pura, / oh arte de intersticios, / de alianza y de fijeza, / cuerpo de semejanzas contra el cielo desnudo». La pintura, ha dicho Sánchez Robayna en un ensayo sobre José María Sicilia (2000: 296), «inmoviliza, fija, detiene. La pintura lucha contra el tiempo y parece detener su curso en un instante que diríamos tangible, material. Al inmovilizar el tiempo, la pintura parece situarse más allá de él, es decir, se instala literalmente en lo intemporal». El cielo desnudo recuerda el «espacio desnudo» (1995: 351) que contiene completamente al hombre y que, como la comarca o «contrada» heideggeriana (Gegend), definida inicialmente como horizonte, pero a 


\section{Tropelías. Revista de Teoría de la Literatura y Literatura Comparada, 29 (2018)}

Alianza y comunión: la poesía como sacramento en la obra de Andrés Sánchez Robayna

continuación como «amplitud que hace demorar, la que, reuniéndolo todo, se abre, de modo que en ella lo abierto es mantenido y sostenido para hacer eclosionar toda cosa en su reposar» (Heidegger, 1989: 47). Por ello el pintor, «que ha podido tocar lo indivisible», se aquieta y se retira, dejando ser a la obra. Morandi parece constituirse en modelo de la piedad zambraniana, al saber tratar con el misterio: no permanece apegado a la obra, sino que sabe desprenderse de ella para salir al mundo, en el que habrá de continuar la actitud de cuidado que devuelve al ser. El silencio muestra la ascesis del pintor, que no solo culmina el cuadro sino que consuma su vida (vive poéticamente).

Retirado el autor, el poema puede entregarse a la celebración plena de la obra. Esta se caracteriza por una doble cara: el vacío y la alianza. El primer rasgo se muestra ya en la técnica escogida del aguafuerte («arte de intersticios» (Sánchez Robayna, 2010: 30). El vacío («espacio vacante») posibilita el juego de correspondencias en el interior («intercambia reflejos») y la presencia del misterio en la luz que es inminencia, pero que aún no se muestra («y el relámpago late en el seno del cielo»). La obra, como hemos visto en el epígrafe anterior, es materia que refiere a una presencia (el mundo), para ahondar en su misterio, dejando ser el mundo en su misterio, devolviéndole la dimensión invisible que una concepción técnica y utilitaria del signo ha amputado: «Oh cuerpo de una alianza, / materia que rehace la materia del mundo, / en tu pigmento se celebra lo abierto». La obra, en efecto, convoca al mundo para que se una en su materia: «Oh luz voluminosa / me ha parecido ver un temblor en los muros / un estremecimiento, como si, / voraz la vibración de lo visible / llegara hasta la tela, quisiera arder con ella». Este estremecimiento (huella de lo sagrado), responde al «temblor» del primer fragmento. La «voracidad» muestra el temblor del deseo que tiende a unificarlo todo: la tela y lo visible; realidad y cuadro. Esta unificación en la carne significante de la materia artística, obrada por el deseo, impulsará una nueva «voracidad», el deseo que se despierta en la mirada del contemplador, que devorará el cuadro y será devorado por él ${ }^{42}$. Esta relación se canta en el tercer fragmento.

Este último se estructura como una plegaria (Sánchez Robayna, 2016: 483):

Hace ya algún tiempo que me persigue la analogía poesía-oración. A fin de cuentas, una y otra crean un objeto (Dios, lo real -quiero decir, su realidad, una realidad). De ahí tal vez, me digo, la tendencia de algunos versos míos últimos -y no tan últimos- a asociarse a la oración, como en el poema dedicado a Morandi, que leeré mañana en Luxemburgo. La expresión de un deseo, de un ruego, dirigido a la gnosis.

El fragmento comienza con una terminología de claro sabor heideggeriano para abrirse a la tradición de las correspondencias, la unidad que late en el mundo y que el artista sabe leer. En esta tradición de las correspondencias, cada ser es símbolo y, como tal, alianza: «Pintor, / que en la proximidad fundas lo abierto, / que en el fulgor de un vaso ves / el reflejo del cielo que arde, el eco de una alianza, / la semejanza que inaugura la forma». El segundo verso recuerda el ensayo «Memoria»(An-denken) de Heidegger (2005: 163): «Así que fundar es ese permanecer que se

\footnotetext{
${ }^{42}$ Este ser devorado por la obra se refleja con claridad en el siguiente poema del libro, «Capella Cornaro», en el que los ojos del espectador se unifican con el conjunto escultórico: «Ojos, dolor, dulzura y sangre y dardo atraviesan sin fin la piedra arrebatada». En este poema se observa la comunión final con la obra de arte, en la que el espectador devora la obra, al tiempo que es devorado por ella.
} 
aproxima al origen y que permanece, porque en cuanto temerosa marcha hacia la fuente sólo con dificultad puede abandonar el lugar de la proximidad». Sin embargo, en Heidegger, el poeta muestra el espacio abierto, no parece fundarlo (si bien en el texto fundar y decir se identifican en ocasiones); en el poema, lo misterioso es fundado por la obra (como en la poética juanramoniana). En la medida en que el poeta permanece abierto al origen (a lo abierto), puede percibir las relaciones de semejanza entre los seres, bajo la luz de lo abierto y, al nombrarlo, les confiere permanencia: los funda en lo que permanece. En esto consiste el «morar originario», «morar fundante cerca del origen» que es «morar poéticamente» (Heidegger, 2005: 165). Apertura al misterio y 'Gelassenheit' se pertenecen (Heidegger, 1989: 28): solo se puede fundar en la proximidad, introduciéndose en ella y comprometiéndose con ella (Heidegger, 1989: 80), mediante un estado de espera continuo (una espera serena, «gelassen») que abandona el propio querer. De ahí la paz del trazo del pintor, pero también su temblor (señal de que trata con el misterio).

El ser del contemplador corresponde con el del pintor y el de los objetos reflejados, pues también él es recipiente:

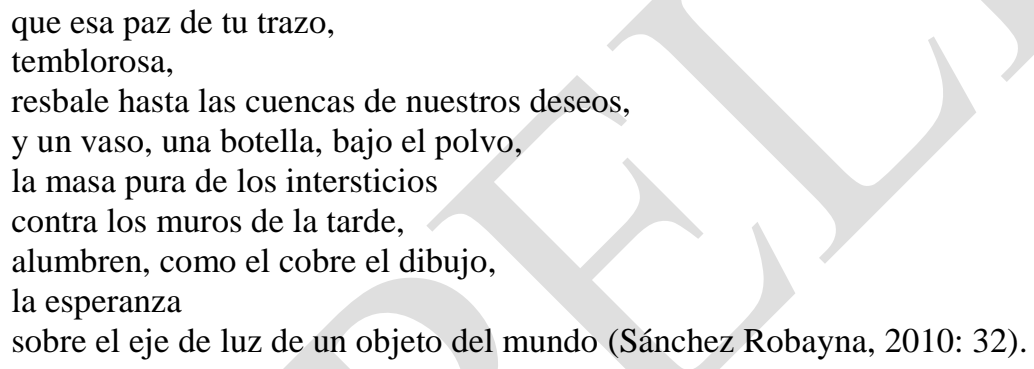

Así como la «obra de lo secreto» afluía en el primer fragmento, ahora resbala «hasta las cuencas de nuestros deseos». La obra suscita el eros, que atrapa al contemplador llevándolo a ella. Así como el cobre se graba en la lámina, ahora el dibujo penetra en el espectador y lo fecunda, haciendo brotar en él la esperanza, abriéndolo a la espera y al futuro, fundando un abrigo (una tregua) ante la muerte. De ahí procede la petición final, demandando precisamente «clemencia» para el «tiempo»: «Que estas palabras lleven al tiempo una clemencia, / que el sol de la materia se derrame sin término». Estos versos finales se encuentran vinculados estrechamente a los que dan fin a «En el cuerpo del mundo» (poema que da título a la obra reunida de Andrés Sánchez Robayna hasta 2002): «Nos cegaste. Seguimos caminando, / a tientas en lo oscuro, hasta encontrar / para siempre ese cuerpo al que abrazarnos, / la cascada de luz, y ahí está la eternidad» (Sánchez Robayna, 2003: 358). La cascada de luz del cuerpo del mundo se corresponde con «el sol de la materia» que se derrama y, en ambos casos, suponen un conjuro ante la muerte. Estos dos versos finales no pueden dejar de recordar la «epíclesis» (invocación del espíritu para que descienda sobre el pan), pero aquí el espíritu es el «sol de la materia», que hemos de entender como suprema realidad ${ }^{43}$. Nos hallamos, pues, ante una mística materialista (en la que espíritu y materia son uno). En la tradición del

43 Cfr. Sánchez Robayna (2016: 196): «Bonnefoy sobre Morandi y Mallarmé: el poema puede contribuir a que la suprema realidad "advenga"». 


\section{Tropelías. Revista de Teoría de la Literatura y Literatura Comparada, 29 (2018)}

Alianza y comunión: la poesía como sacramento en la obra de Andrés Sánchez Robayna

Romanticismo (según vimos al inicio del presente trabajo), el arte es el «depositario de la experiencia religiosa ${ }^{44}$, si bien (como observa Abrams), son la naturaleza y el hombre los que ostentan los atributos de la divinidad. La obra re-liga lo dividido (mundo, hombre y misterio); el lector ha de abrazarse a este cuerpo del poema (unirse a él, tragarlo) para enlazarse así con lo sagrado.

\section{Bibliografía}

Abrams, M. H. (1992): El Romanticismo: Tradición y Revolución. Traducción de T. SEgOviA. Madrid, Visor.

Blasco Pascual, F. J. (1981): La poética de Juan Ramón Jiménez. Desarrollo, contexto y sistema. Salamanca, Ediciones Universidad de Salamanca.

De Eusebio, C. (2015): «Andrés Sánchez Robayna: “el mundo se celebra en los ojos”», Cuadernos hispanoamericanos, 780, pp. 50-58.

DOMÍNGUEZ CAPARRós, J. (2010): Métrica y poética: bases para la fundamentación de la métrica en la teoría literaria moderna. Madrid, UNED.

GómEZ-MonTERo, J. (2012): «Lectura y escucha del mundo: la escritura de Andrés Sánchez Robayna ante la tradición mística», Siglo XXI, literatura y cultura españolas: revista de la Cátedra Miguel Delibes, 9-10, pp. 173-188.

GutiÉRrez Pozo, A. (2003): «Arte y Gelassenheit. Estética, ética y lógica originarias en el pensar de Heidegger», LOGOS. Anales del Seminario de Metafísica, 36, pp. 153-186.

Heidegger, M. (1958): Arte y poesía. Traducción de S. Ramos. México D.F., Fondo de Cultura Económica.

(1989): Serenidad. Traducción de Y. ZiMMERMANN. Barcelona, Ediciones del Serbal.

(1994): Conferencias y artículos. Traducción de E. BARJAU. Barcelona, Ediciones del Serbal, $2^{a}$ edición revisada, 2001.

— (2005): Aclaraciones a la poesía de Hölderlin. Traducción de H. CoRTÉs GabaudÁn y A. LEYTE COELLo. Madrid, Alianza Editorial.

Hulin, M. (2007): La mística salvaje. En los antípodas del espíritu. Traducción de M. TABUYO y A. LÓPEZ. Madrid, Ediciones Siruela.

JiMÉNEZ, J. R. (1999): Lírica de una Atlántida. Barcelona, Galaxia Gutenberg.

OTTO, R. (1985): Lo santo. Lo racional y lo irracional en la idea de Dios. Traducción de F. VelA. Madrid, Alianza.

PAZ, O. (1956). El arco y la lira. México D.F., Fondo de Cultura Económica, $3^{\text {a }}$ edición, 1972.

PeinAdo Elliot, C. (2010): «El poema como cuerpo litúrgico: "Luz de Fuerteventura”, de Andrés Sánchez Robayna», en M. NIETO, coord., Literatura y comunicación. Madrid, Castalia, pp. 255-286.

\footnotetext{
${ }^{44}$ Sánchez Robayna (2016: 541-542) considera el arte «depositario de la experiencia religiosa (de la religiosidad) ante una religión que no supo y no sabe serlo y que se ha fosilizado en pura institución».
} 
SÁnchez Robayna, A. (1985): La luz negra (Ensayos y notas, 1974-1984). Gijón, Ediciones Júcar. (1995): «Deseo, imagen, lugar de la palabra» en Deseo, imagen, lugar de la palabra. Barcelona, Galaxia Gutenberg, 2008, pp. 345-363.

(1996): La inminencia (Diarios, 1980-1995). Madrid, Fondo de Cultura Económica.

(1998): «Mallarmé y el saber de la nada» en Deseo, imagen, lugar de la palabra. Barcelona, Galaxia Gutenberg, 2008, pp. 11-22.

- (2000): «Bajo el abrigo céreo: la pintura de José María Sicilia», en Deseo, imagen, lugar de la palabra. Barcelona, Galaxia Gutenberg, 2008, pp.283-296.

- (2002): Días y mitos (Diarios, 1996-2000). México D.F., Fondo de Cultura Económica.

- (2004): En el cuerpo del mundo. Obra poética (1970-2002). Barcelona, Galaxia Gutenberg.

_ (2008a): Deseo, imagen, lugar de la palabra. Barcelona, Galaxia Gutenberg.

- (2008b): «Bajo puentes de silencio», Revista de Occidente, 323, pp. 143-149.

- (2010): La sombra y la apariencia. Barcelona, Tusquets Editores.

- (2011a): Cuaderno de las islas. Barcelona, Lumen.

- (2011b): «Meditación sobre el arquero», Cuadernos Hispanoamericanos, 734, pp.11-17.

- (2015): Variaciones sobre el vaso de agua. Barcelona, Galaxia Gutenberg.

- (2016): Mundo, año, hombre (Diarios, 2001-2007). Madrid, Fondo de Cultura Económica.

SteIner, G. (2001): Presencias reales. ¿Hay algo en lo que decimos? Traducción de J. G. LóPEZGuIX. Barcelona, Ediciones Destino.

TAUBES, J. (2007): Del culto a la cultura. Elementos para una crítica de la razón histórica. Traducción de S. VILLEgas. Buenos Aires, Madrid, Katz.

VALENTE, J. Á. (2008): Obras completas, 2: Ensayos. Barcelona, Galaxia Gutenberg.

TRÍAS, E. (1994): La edad del espíritu. Barcelona, Ediciones Destino.

XIRAU, R. (1980): Dos poetas y lo sagrado. México D.F., Cuadernos de Joaquín Mortiz.

Zambrano, M. (1955): El hombre y lo divino. México D. F., Fondo de Cultura Económica, $2^{\mathrm{a}}$ ed. (aumentada), 1973.

- (1996): La Cuba secreta y otros ensayos. Madrid, Endymion.

_ (2007): Algunos lugares de la poesía. Madrid, Editorial Trotta.

ZUBIRI, X. (1984): El hombre y Dios. Madrid, Alianza Editorial, 4ª edición, 1988. 